\title{
Oxidation of Methionine by Human
}

\section{Polymorphonuclear Leukocytes}

\author{
Min-Fu Tsan and Jasmine W. Chen, Divisions of Hematology and Nuclear Medicine, \\ The Johns Hopkins Medical Institutions, Baltimore, Maryland 21205
}

A B S T R A C T Studies of the photosensitized oxidation have demonstrated that photodynamic oxidation of methionine is mediated by singlet oxygen $\left({ }^{1} \mathrm{O}_{2}\right)$. In this study, we demonstrated that phagocytosing human polymorphonuclear leukocytes (PMN), but not resting PMN, oxidized both intracellular and extracellular methionine to methionine sulfoxide. $N$-ethylmaleimide, which inhibits phagocytosis and cellular metabolism, inhibited the oxidation of methionine. Neutrophils from patients with chronic granulomatous disease did not oxidize methionine even in the presence of phagocytosis. The oxidation of methionine by phagocytosing normal PMN was inhibited by ${ }^{1} \mathrm{O}_{2}$ quenchers, (1.4diazabicyclo-[2,2,2]-octane, tryptophan, $\mathrm{NaN}_{3}$ ), myeloperoxidase (MPO) inhibitors $\left(\mathrm{NaN}_{3}, \mathrm{KCN}\right)$ and catalase. In contrast, superoxide dismutase, ethanol, and mannitol had no effect. Furthermore, ${ }^{1} \mathrm{O}_{2}$ quenchers did not interfere with the production of superoxide $\left(\mathrm{O}_{2}^{-}\right)$by phagocytosing $\mathrm{PMN}$. The combination of catalase and SOD did not enhance the inhibition of methionine by phagocytosing PMN. On the other hand, deuterium oxide stimulated the oxidation of methionine by PMN almost $200 \%$.

$\mathrm{H}_{2} \mathrm{O}_{2}$ at high concentrations oxidized methionine to methionine sulfoxide. However, when similar amounts of $\mathrm{H}_{2} \mathrm{O}_{2}$ were added to human $\mathrm{PMN}$, they did not oxidize methionine. In contrast, when $\mathrm{H}_{2} \mathrm{O}_{2}$, at concentrations too low to oxidize methionine by itself, was added to the granular fraction, but not the soluble fraction, they oxidized methionine to methionine sulfoxide. The oxidation of methionine by the combination of $\mathrm{H}_{2} \mathrm{O}_{2}$ and granular fractions was inhibited by ${ }^{1} \mathrm{O}_{2}$ quenchers and MPO inhibitors, but it was stimulated by deuterium oxide. Removal of chloride anion also

Dr. Tsan is the recipient of a Research Career Development Award (AI-00194) from the National Institute of Allergy and Infectious Diseases. Address reprint requests to Dr. Tsan.

Received for publication 10 September 1979 and in revised form 18 January 1980. prevented the oxidation of methionine by the granular fractions.

Our results suggest that the oxidation of methionine by phagocytosing PMN is dependent on the MPOmediated antimicrobial system ( $\left.\mathrm{MPO}-\mathrm{H}_{2} \mathrm{O}_{2}-\mathrm{Cl}^{-}\right)$. They also suggest, but do not prove that the oxidation of methionine is mediated by ${ }^{1} \mathrm{O}_{2}$. Oxidation of methionine may be one of the mechanisms that human PMN damage microorganisms.

\section{INTRODUCTION}

Ingestion of particles by polymorphonuclear leukocytes $(\mathrm{PMN})^{1}$ is accompanied by the production of several reactive oxygen metabolites that have been implicated in the killing of ingested microorganisms (1). The one electron reduction of molecular oxygen results in the production of superoxide $\left(\mathrm{O}_{2}^{-}\right)(2)$. In human PMN, a pyridine nucleotide oxidase appears to catalyze this reaction (3). Superoxide may then dismutate, either spontaneously or under the enzymatic action of superoxide dismutase (SOD), producing $\mathrm{H}_{2} \mathrm{O}_{2}$ (1). Recent evidence suggests that $\mathrm{O}_{2}^{-}$and $\mathrm{H}_{2} \mathrm{O}_{2}$, in turn, are precursors of more powerful oxidizing agents such as hydroxyl radical $(\mathrm{OH}).(4)$ or singlet oxygen $\left({ }^{1} \mathrm{O}_{2}\right)(5)$.

Singlet oxygen is an excited state of molecular oxygen in which an electron has been shifted to an orbital of higher energy (6). The excessive energy of ${ }^{1} \mathrm{O}_{2}$ can be dissipated by the emission of light, by thermal decay or by its participation in characteristic chemical reactions. In 1972, Allen et al. (7) observed the emission of light by PMN during phagocytosis and suggested that this was due to the production of ${ }^{1} \mathrm{O}_{2}$. However, extensive studies (8) have shown that ${ }^{1} \mathrm{O}_{2}$ per se contributes little, if anything, to the luminescence of phagocytosing PMN, and that light emission during

\footnotetext{
${ }^{1}$ Abbreviations used in this paper: CGD, chronic granulomatous disease; DABCO, 1.4-diazabicyclo-[2,2,2]-octane; $\mathrm{D}_{2} \mathrm{O}$, deuterium oxide; MPO, myeloperoxide; $\mathrm{PMN}$, polymorphonuclear leukocytes; $\mathrm{SOD}$, superoxide dismutase.
} 
phagocytosis is most likely the result of reactions between certain unspecified constituents of the ingested particles and some or all of the oxidizing agents produced by phagocytosing cells. In 1974, Krinsky (9) observed that human PMN killed a colorless mutant strain of Sarcina lutea much more readily than a carotenoid-containing strain and suggested that singlet excited oxygen acted as one of the mediators of PMN bactericidal action. More recently, Rosen and Klebanoff (5) demonstrated the conversion of diphenylfuran to cis-dibenzoyl ethylene by the combination of myeloperoxidase (MPO), $\mathrm{H}_{2} \mathrm{O}_{2}$, and chloride anion, a MPOmediated bactericidal system present in PMN. They suggested that this chemical conversion was due to the production of ${ }^{1} \mathrm{O}_{2}$ by the MPO-mediated bactericidal system. However, Harrison et al. (10) showed that the conversion of diphenylfuran to cis-dibenzoyl ethylene, the presumed ${ }^{1} \mathrm{O}_{2}$ reaction, by the $\mathrm{MPO}-\mathrm{H}_{2} \mathrm{O}_{2}-\mathrm{Cl}^{-}$ system was due to the generation of $\mathrm{Cl}_{2}$, not ${ }^{1} \mathrm{O}_{2}$.

Studies of the photosensitized oxidation have demonstrated that photodynamic oxidation of methionine is mediated by ${ }^{1} \mathrm{O}_{2}(11,12)$. At low to neutral $\mathrm{pH}$, two molecules of methionine are oxidized to methionine sulfoxide by one molecule of ${ }^{1} \mathrm{O}_{2}$ according to the following reaction $(11,12)$ :

$\underset{\substack{\mathrm{NH}_{2}\\}}{2 \mathrm{CH}_{3} \mathrm{SCH}_{2} \mathrm{CH}_{2} \mathrm{CHCOOH}+{ }^{1} \mathrm{O}_{2} \rightarrow}$

We have studied the oxidation of methionine by human PMN. The results of this study form the basis of this report.

\section{METHODS}

Chemicals. L- $\left[\mathrm{U}-{ }^{14} \mathrm{C}\right]$ methionine was obtained from New England Nuclear, Boston, Mass. L-methionine, L-methionineDL-sulfoxide, guaiacol, catalase ${ }^{2}$ (bovine liver, EC 1.11.1.6) and SOD (bovine blood EC 1.15.1.1) were obtained from Sigma Chemical Co., St. Louis, Mo. 1.4-diazabicyclo-[2,2,2]octane (DABCO) was obtained from Eastman Organic Chemicals Div., Eastman Kodak Co., Rochester, N. Y. Sodium hypochlorite was the product of Mallinckrodt, Inc., St. Louis, Mo. and was standardized by reaction with $\mathrm{KI}$ and spectrophotometric measurement of the $I_{3}^{-}$formed using $\mathrm{E}_{353}=2.64 \times 10^{4} \mathrm{M}^{-1} \mathrm{~cm}^{-1}(13)$. Deuterium oxide $\left(\mathrm{D}_{2} \mathrm{O}\right)$ was obtained from ICN Pharmaceuticals, Inc., Irvine, Calif. Polystyrene latex $(0.79 \mu \mathrm{m}$ Diam $)$ were obtained from the Dow Corning Corp., Midland, Mich.

\footnotetext{
${ }^{2}$ Catalase, $3,400 \mathrm{U} / \mathrm{mg}$, one unit decomposes $1 \mu \mathrm{mol}$ of $\mathrm{H}_{2} \mathrm{O}_{2} /$ min at $\mathrm{pH} 7.025^{\circ} \mathrm{C}$, whereas $\mathrm{H}_{2} \mathrm{O}_{2}$ concentration falls from $10.3-9.2 \mu \mathrm{mol} / \mathrm{ml}$ of reaction mixture. Superoxide dismutase, 2,810 U/mg. Assayed per method of McCord and Fidovich (J. Biol. Chem. 244: 6049, 1969).
}

Isolation of human P.MN and preparation of cell fractions. These were performed as described previously $(14,15)$.

Oxidation of methionine by human PMN. To $50 \mathrm{ml}$ conical plastic centrifuge tubes, the following were added in a final vol of $1 \mathrm{ml}: 1.5 \times 10^{7} \mathrm{PMN}$ and $0.1 \mu \mathrm{Ci}\left[{ }^{14} \mathrm{C}\right]$ methionine (final concentration, $22 \mu \mathrm{M}$ unless otherwise indicated). In the tubes designated for phagocytosis, polystyrene latex particles were added to a final concentration of $0.17 \%$ (by weight), which provided more than 100 particles per cell. Experimental additions yielded the final concentrations of the chemicals as indicated in the table legends. The tubes then were incubated at $37^{\circ} \mathrm{C}$ for $30 \mathrm{~min}$ in a waterbath with constant shaking. At the end of incubation, the tubes were immersed in ice and immediately centrifuged at $1,000 \mathrm{~g}$ for $5 \mathrm{~min}$ at $4^{\circ} \mathrm{C}$. The supernate was saved for paper chromatoggraphy. In some experiments, the pellet was washed once with $5 \mathrm{ml}$ cold modified Hanks' solution, the cells were then extracted with $1 \mathrm{ml}$ distilled water in ice for $1 \mathrm{~h}$. After centrifugation at $1,000 \mathrm{~g}$ for $5 \mathrm{~min}$ at $4^{\circ} \mathrm{C}$, the water extract was chromatographed to determine the intracellular oxidation of methionine.

The ascending paper chromatography with three different solvent systems, which gave adequate separation of methionine from methionine sulfoxide (16) was used. These solvent systems are $(a)$ t-butanol:methylethylketone: $\mathrm{H}_{2} \mathrm{O}$ :ammonium hydroxide, 40:30:20:10; (b) $n$-butanol:glacial acetic acid: $\mathrm{H}_{2} \mathrm{O}$, 50:25:2.5; and (c) t-butanol:methylethylketone:formic acid: $\mathrm{H}_{2} \mathrm{O}$, 40:30:15:15. Control methionine and methionine sulfoxide were always cochromatographed with the samples. After the development, ninhydrin was used to identify control methionine and methionine sulfoxide, and the $R_{f}$ values calculated. The chromatograms that contained the samples were cut into $1 \times 2 \mathrm{~cm}$ strips, which were placed in vials and counted by liquid scintillation in a toluene-based solution. About $20 \mu$ l of the samples were chromatographed and the recovery of radioactivity was $>95 \%$. The results were plotted on the graph papers and the $R_{\mathrm{f}}$ values compared to those of control methionine and methionine sulfoxide. In the initial experiments, all three solvent systems were used. The $R_{f}$ values of the oxidative product of $\left[{ }^{14} \mathrm{C}\right]$ methionine were identical to those of methionine sulfoxide in all three solvent systems. Subsequently, only system I was used routinely. ${ }^{3}$ In each experiment, a $\left[{ }^{14} \mathrm{C}\right]$ methionine standard was also cochromatographed to determine the spontaneous oxidation of methionine during the procedure and the results were corrected accordingly.

Oxidation of methionine by the cell fractions. To 12 $\times 75 \mathrm{~mm}$ plastic test tubes, the following were added in a final vol of $0.5 \mathrm{ml}$ in modified Hanks' solution: soluble or granular fraction $\left(0.15 \mathrm{mg}\right.$ protein) and $0.1 \mu \mathrm{Ci}\left[{ }^{14} \mathrm{C}\right]$ methionine $(22 \mu \mathrm{M})$. Experimental additions yielded the final concentrations of the chemicals as indicated in the tables. The tubes then were incubated at $37^{\circ} \mathrm{C}$ for $30 \mathrm{~min}$ in a waterbath with constant shaking. At the end of incubation, the tubes were immersed in ice and immediately centrifuged at $1,000 \mathrm{~g}$ for $5 \mathrm{~min}$ at $4^{\circ} \mathrm{C}$. The supernate was chromatographed to determine the oxidation of methionine as described above.

Other studies. The fate of methionine in human PMN was analyzed by determining which fractions of radioactivity were acid soluble and acid insoluble as described previously (17). The myeloperoxidase activity of the granular fractions was determined according to Michell et al. (18) and the photodynamic oxidation of methionine by methylene blue was

\footnotetext{
${ }^{3}$ Solvent system I can also separate methionine sulfone from methionine and methionine sulfoxide (23). Thoughout the entire study, no $\left[{ }^{14} \mathrm{C}\right]$ methionine sulfone was observed.
} 


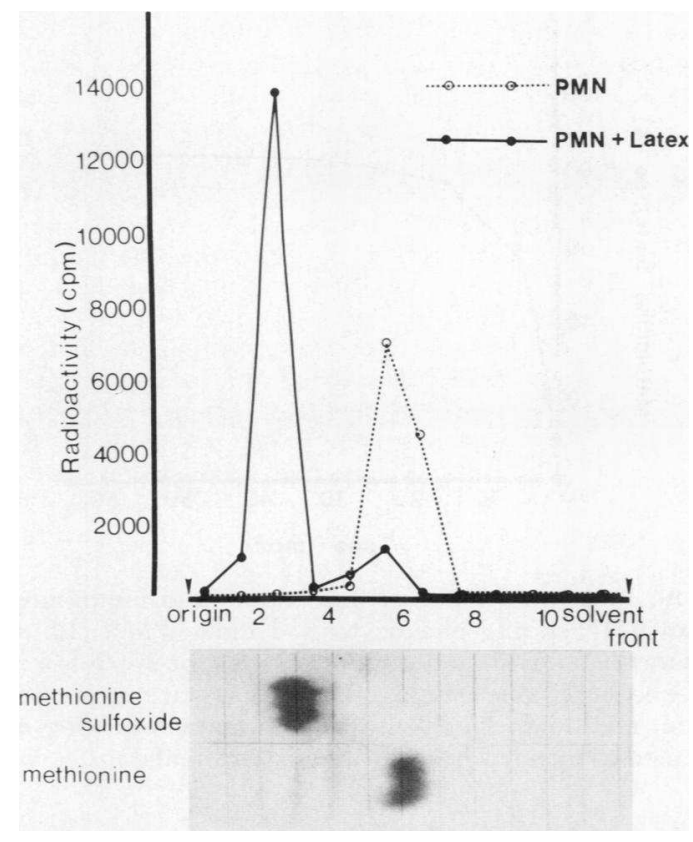

FIGURE 1 Chromatographic separation of methionine and methionine sulfoxide. Cells were incubated with $\left[{ }^{14} \mathrm{C}\right] \mathrm{methi}-$ onine in the presence or absence of latex particles for 30 min at $37^{\circ} \mathrm{C}$. The final media were then chromatographed by ascending paper chromatography using t-butanol:methylethylketone: $\mathrm{H}_{2} \mathrm{O}$ :ammonium hydroxide (40:30:20:10).

performed according to Jori et al. (11). Superoxide production by human PMN was measured by SOD-inhibitable reduction of ferricytochrome $c$ according to Babior et al. (2) as described previously (14). Hydrogen peroxide production was determined by the disappearance of scopoletin fluorescence in the presence of horseradish peroxidase as described previously (19). The effect of $\mathrm{D}_{2} \mathrm{O}$ on the oxidation of methionine by $\mathrm{PMN}$, granular fraction or methylene blue was carried out by substituting $\mathrm{H}_{2} \mathrm{O}$ with $\mathrm{D}_{2} \mathrm{O}$ to a final concentration of $60 \% \mathrm{D}_{2} \mathrm{O}$.

Statistical analysis. Statistical differences were determined using Student's $t$ test for independent means (20).

\section{RESULTS}

Oxidation of methionine by human PMN. Using ascending paper chromatography with three different solvent systems, we demonstrated that in the presence of latex particles, methionine was oxidized to methionine sulfoxide by human PMN. Fig. 1 shows one of the typical experiments. After $30 \mathrm{~min}$ incubation, $86 \%$ of methionine present in the final medium was oxidized to methionine sulfoxide by human PMN in the presence of latex particles; whereas in the absence of latex particles, none of the methionine was oxidized.

Fig. 2A shows the amount of methionine taken up by human PMN at various substrate concentrations $(12-62 \mu \mathrm{M})$. Resting PMN took up more methionine than phagocytosing PMN. The fractions of methionine taken up by the cells were small; for example, at a concentration of $22 \mu \mathrm{M}$, only 5 and $1.5 \%$ of methionine was taken up by resting and phagocytosing PMN, respectively. Quantification of the acid soluble and acid insoluble fractions revealed that $<10 \%$ of the methionine taken up by the cells were incorporated into protein (acid-insoluble fraction).

Fig. 2B shows the oxidation of methionine by human
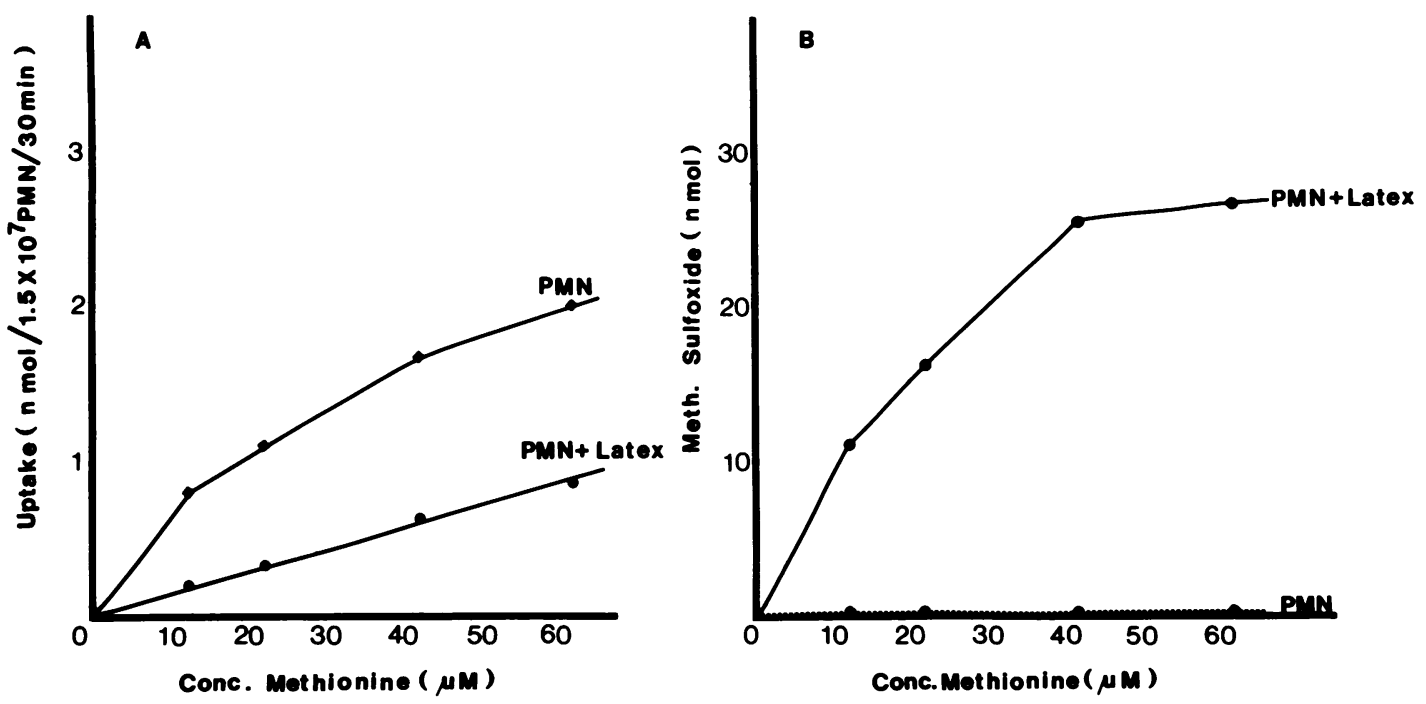

FIgURE 2 (A) Methionine uptake and (B) oxidation of methionine by human PMN. Human PMN $\left(1.5 \times 10^{7}\right)$ were incubated with methionine at various concentrations (conc) $(12-62 \mu \mathrm{M})$ for $30 \mathrm{~min}$ in the presence or absence of latex particles. The amount of methionine uptake by the cells or the amount of methionine oxidized to methionine sulfoxide in the final media were then determined. Each point represents the mean of two experiments. 
PMN at various concentrations of methionine. In this study, only the oxidation of extracellular methionine was determined. The amounts of methionine sulfoxide produced by phagocytosing PMN increased with increasing concentrations of methionine in the medium; it reached a plateau at a methionine concentration of $42 \mu \mathrm{M}$. In contrast, resting PMN did not oxidize methionine to methionine sulfoxide.

Most of our subsequent experiments were done with a methionine concentration of $22 \mu \mathrm{M}$. At this concentration, about $80 \%$ of methionine was oxidized to methionine sulfoxide by phagocytosing PMN; it gave us excellent sensitivity for testing the effect of various inhibitors. Table I summarizes some of our results. After 30 min incubation, $1.5 \%$ of methionine was taken up by the phagocytosing cells (see above). Of this, $77 \%$ was oxidized to methionine sulfoxide. Likewise, $80 \%$ of the methionine remaining in the medium was oxidized to methionine sulfoxide. In contrast, practically none of the extracellular and intracellular methionine was oxidized to methionine sulfoxide by resting PMN. $N$-ethylmaleimide, which inhibits phagocytosis and metabolic events associated with the activation of PMN (21), inhibited the oxidation of methionine by PMN in the presence of latex particles. This suggests that the metabolic event associated with phagocytosis is responsible for the oxidation of methionine to methionine sulfoxide. Since the majority of methionine remained in the medium, subsequent studies were performed to determine the oxidation of extracellular methionine only.

Fig. 3 shows a time-course of the oxidation of methionine by phagocytosing PMN. The oxidation of methionine was rapid; it reaches a plateau after incubation for $15 \mathrm{~min}$. This suggests that the agent responsible

TABLE I

Oxidation of Methionine by Human PMN*

Methionine sulfoxide

$\%$

Resting cells

Intracellular $(5 \%) \ddagger$

Extracellular (95\%)

$1.0 \pm 0.6(3) \S$

$1.1 \pm 0.6(9)$

Phagocytosing cells

Intracellular (1.5\%)

Extracellular (98.5\%)

$77.0 \pm 0.6(3)$

$80.0 \pm 6.1(9)$

$+1 \mathrm{mM} n$-ethylmaleimide

$1.0 \pm 0.4(4)$

* The results are expressed as mean \pm 1 SEM of the percentage of methionine oxidized to methionine sulfoxide. PMN $\left(1.5 \times 10^{7}\right)$ were incubated with $0.1 \mu \mathrm{Ci}$ of $\left[{ }^{14} \mathrm{C}\right]$ methionine $(22 \mu \mathrm{M})$ in the presence or absence of latex particles or $n$-ethylmaleimide for $30 \mathrm{~min}$ at $37^{\circ} \mathrm{C}$.

$\ddagger$ Percentage of the total radioactivity at the end of incubation. $\S$ Number of experiments.

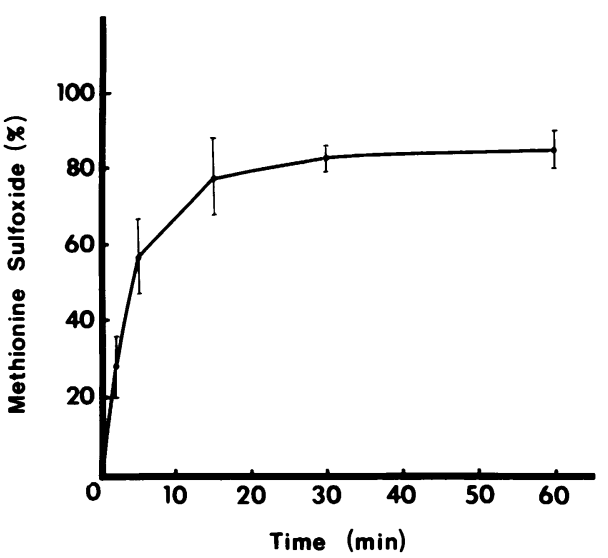

Figure 3 A time-course of the oxidation of methionine by human PMN during phagocytosis. Human PMN $\left(1.5 \times 10^{7}\right)$ were incubated with methionine $(22 \mu \mathrm{M})$ for $2-60 \mathrm{~min}$ in the presence of latex particles. The results are expressed as percent methionine oxidized to methionine sulfoxide in the final media (mean \pm SEM of three experiments).

for the oxidation of methionine is produced at the early phase of phagocytosis.

Oxidation of methionine by PMN from patients with chronic granulomatous disease (CGD). Neutrophils from patients with CGD ingest particles normally, but fail to produce $\mathrm{O}_{2}^{-}, \mathrm{H}_{2} \mathrm{O}_{2}$, and $\mathrm{OH} \cdot$ normally associated with phagocytosis (1). As a consequence, CGD patients suffer from recurrent, severe infections. Neutrophils from two unrelated patients with X-linked CGD were studied; CGD PMN did not oxidize methionine to methionine sulfoxide even in the presence of latex particles (two experiments, data not shown).

Effect of singlet oxygen quenchers on the oxidation of methionine by human PMN. To determine the agent (or agents) responsible for the oxidation of methionine by phagocytosing PMN, the effect of ${ }^{1} \mathrm{O}_{2}$ quenchers was first studied. Many of the known ${ }^{1} \mathrm{O}_{2}$ quenchers such as $\beta$-carotene, dimethylfuran (12) are lipid soluble with very limited water solubility. In this study, we only used the water soluble ${ }^{1} \mathrm{O}_{2}$ quenchers, DABCO (22), tryptophan (12), and $\mathrm{NaN}_{3}$ (23). As shown in Table II, all these ${ }^{1} \mathrm{O}_{2}$ quenchers prevented the oxidation of methionine by phagocytosing PMN. Other amino acids, lysine, and glycine, had no effect (three experiments, data not shown). At similar concentrations, these ${ }^{1} \mathrm{O}_{2}$ quenchers did not have any effect on the $\mathrm{O}_{2}^{-}$production by human PMN either at rest or during phagocytosis (three experiments, data not shown).

Since $\mathrm{NaN}_{3}$ is known to inhibit heme enzymes such as MPO or catalase; $\mathrm{KCN}$, an inhibitor of heme enzymes but not a ${ }^{1} \mathrm{O}_{2}$ quencher (5), was also studied. As shown in Fig. 4, both $\mathrm{NaN}_{3}$ and KCN inhibited the oxidation of methionine by human PMN during phagocytosis. However, $\mathrm{NaN}_{3}$ was about 10 times more potent than $\mathrm{KCN}$ in inhibiting methionine oxidation, al- 
TABLE II

Effect of ${ }^{1} \mathrm{O}_{2}$ Quenchers on the Oxidation of Methionine by Phagocytosing P.MN*

\begin{tabular}{lcc}
\hline & Methionine sulfoxide & $P$ values \\
\hline & $\%$ & \\
Control & $78.2 \pm 5.9(5)$ & \\
+ DABCO (5 $\mathrm{mM})$ & $7.7 \pm 4.9(5)$ & $<0.001$ \\
+ Tryptophan $(1 \mathrm{mM})$ & $3.3 .0 \pm 6.4(4)$ & $<0.005$ \\
$+\mathrm{NaN}_{3}(0.1 \mathrm{mM})$ & $26.0 \pm 2.9(5)$ & $<0.001$ \\
\hline
\end{tabular}

${ }^{*}$ The results are expressed on the same basis as in Table I.

though $\mathrm{KCN}$ is a more potent inhibitor of MPO (24) (also see below).

Effect of SOD and catalase on the oxidation of methionine by human PMN. The effect of SOD and catalase was also studied. As shown in Table III, SOD had no effect on the oxidation of methionine by phagocytosing PMN. In contrast, catalase markedly inhibited the oxidation of methionine. The combination of SOD and catalase did not increase the inhibition suggesting that hydroxyl radicals were not involved. Other hydroxyl radical scavengers such as ethanol and mannitol also had no effect on the oxidation of methionine by phagocytosing PMN. (Table III)

Effect of $\mathrm{H}_{2} \mathrm{O}_{2}$ on the oxidation of methionine by human PMN. The above results indicate that at least part of the methionine oxidation by phagocytosing PMN is dependant on $\mathrm{H}_{2} \mathrm{O}_{2}$. Since $\mathrm{H}_{2} \mathrm{O}_{2}$ is known to oxidize methionine to methionine sulfoxide (25), we studied the effect of exogenous $\mathrm{H}_{2} \mathrm{O}_{2}$ on the oxidation of methionine by human PMN. As shown in Fig. $5, \mathrm{H}_{2} \mathrm{O}_{2}$ oxidized methionine to methionine sulfoxide at relatively high concentrations, e.g., at a concentration of $1 \mathrm{mM}$, it oxidized $45 \%$ of the methionine. However, when the same amounts of $\mathrm{H}_{2} \mathrm{O}_{2}$ were added to human

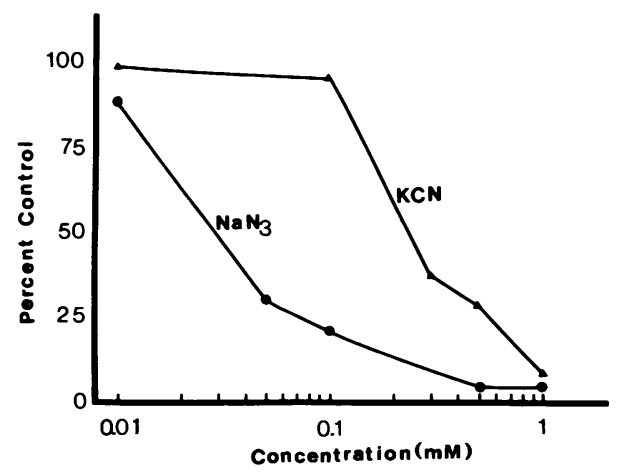

FIgURE 4 The effect of $\mathrm{NaN}_{3}$ and $\mathrm{KCN}$ on the oxidation of methionine by human PMN during phagocytosis. Human PMN $\left(1.5 \times 10^{7}\right)$ were incubated with methionine $(22 \mu \mathrm{M})$ and latex particles for $30 \mathrm{~min}$ at $37^{\circ} \mathrm{C}$ in the presence or absence of $\mathrm{KCN}$ or $\mathrm{NaN}_{3}$. Each point represents the mean of two to four experiments.
TABLE III

Effect of SOD, Catalase and Hydroxyl Radical Scavengers on the Oxidation of Methionine by Human Phagocytosing PMN*

\begin{tabular}{|c|c|c|}
\hline & Methionine sulfoxide & $\begin{array}{l}\text { Percent } \\
\text { control }\end{array}$ \\
\hline & $\%$ & \\
\hline $\begin{array}{l}\text { Control } \\
\quad+\text { SOD }\end{array}$ & $81.3 \pm 6.5(3)$ & \\
\hline $400 \mathrm{U} / \mathrm{ml}$ & $86.2 \pm 8.6(3)$ & 106 \\
\hline $800 \mathrm{U} / \mathrm{ml}$ & $85.3 \pm 8.1(3)$ & 105 \\
\hline + Catalase & & \\
\hline $100 \mathrm{U} / \mathrm{ml}$ & $59.3 \pm 4.8(3) \ddagger$ & 73 \\
\hline $500 \mathrm{U} / \mathrm{ml}$ & $51.0 \pm 3.2(3) \ddagger$ & 63 \\
\hline $1,000 \mathrm{U} / \mathrm{ml}$ & $15.4 \pm 1.8(3) \ddagger$ & 19 \\
\hline $1,000 \mathrm{U} / \mathrm{ml}$ heat inactivated & $78.0 \pm 5.9(3)$ & 96 \\
\hline $\begin{array}{l}+(\text { SOD } 100 \mathrm{U} / \mathrm{ml} \\
+ \text { catalase } 100 \mathrm{U} / \mathrm{ml})\end{array}$ & $61.8 \pm 1.4(2)$ & 76 \\
\hline $\begin{array}{l}+(\text { SOD } 400 \mathrm{U} / \mathrm{ml} \\
+ \text { catalase } 500 \mathrm{U} / \mathrm{ml})\end{array}$ & $47.9 \pm 9.4(3) \ddagger$ & 59 \\
\hline + Ethanol $50 \mathrm{mM}$ & $85.2 \pm 3.1(3)$ & 104 \\
\hline + Mannitol $50 \mathrm{mM}$ & $79.5 \pm 4.2(3)$ & 98 \\
\hline
\end{tabular}

* The results are expressed on the same basis as in Table $I$. There was no statistical difference between catalase $100 \mathrm{U} / \mathrm{ml}$ and catalase $100 \mathrm{U} / \mathrm{ml}+$ SOD $100 \mathrm{U} / \mathrm{ml}$; catalase $500 \mathrm{U} / \mathrm{ml}$ and catalase $500 \mathrm{U} / \mathrm{ml}+$ SOD $400 \mathrm{U} / \mathrm{ml}$.

$\ddagger P<0.05$ or less (vs. control).

PMN, it did not oxidize either intracellular or extracellular methionine to a great extent. This is most likely due to the removal of $\mathrm{H}_{2} \mathrm{O}_{2}$ by catalase present in the cells. Direct quantification of $\mathrm{H}_{2} \mathrm{O}_{2}$ production by phagocytosing PMN in the presence of $2 \mathrm{mM} \mathrm{NaN}_{3}$ to inhibit the cellular destruction of $\mathrm{H}_{2} \mathrm{O}_{2}$ (19) revealed that $637.5 \pm 60.3 \mathrm{nmol}(n=4)$ of $\mathrm{H}_{2} \mathrm{O}_{2}$ were produced by $1.5 \times 10^{7} \mathrm{PMN}$ after $30 \mathrm{~min}$ incubation. This resulted in a final $\mathrm{H}_{2} \mathrm{O}_{2}$ concentration of about $0.6 \mathrm{mM}$.

Oxidation of methionine by the granular fraction of human PMN. In contrast to the above observation, when $\mathrm{H}_{2} \mathrm{O}_{2}$ at concentrations (0.01-0.2 mM) too low to oxidize methionine, was added to the granular fractions of human PMN, it oxidized methionine to methionine sulfoxide (Table IV). In the absence of $\mathrm{H}_{2} \mathrm{O}_{2}$, the granular fraction did not oxidize methionine. When similar amounts of $\mathrm{H}_{2} \mathrm{O}_{2}$ were added to the soluble fractions, there was no oxidation of methionine. Thus, the granular fraction of human PMN markedly enhanced the ability of $\mathrm{H}_{2} \mathrm{O}_{2}$ to oxidize methionine.

Effect of ${ }^{1} \mathrm{O}_{2}$ quenchers and MPO inhibitors on the oxidation of methionine by the granular fraction. The effect of ${ }^{1} \mathrm{O}_{2}$ quenchers and MPO inhibitors on the oxidation of methionine by the granular fraction was then 


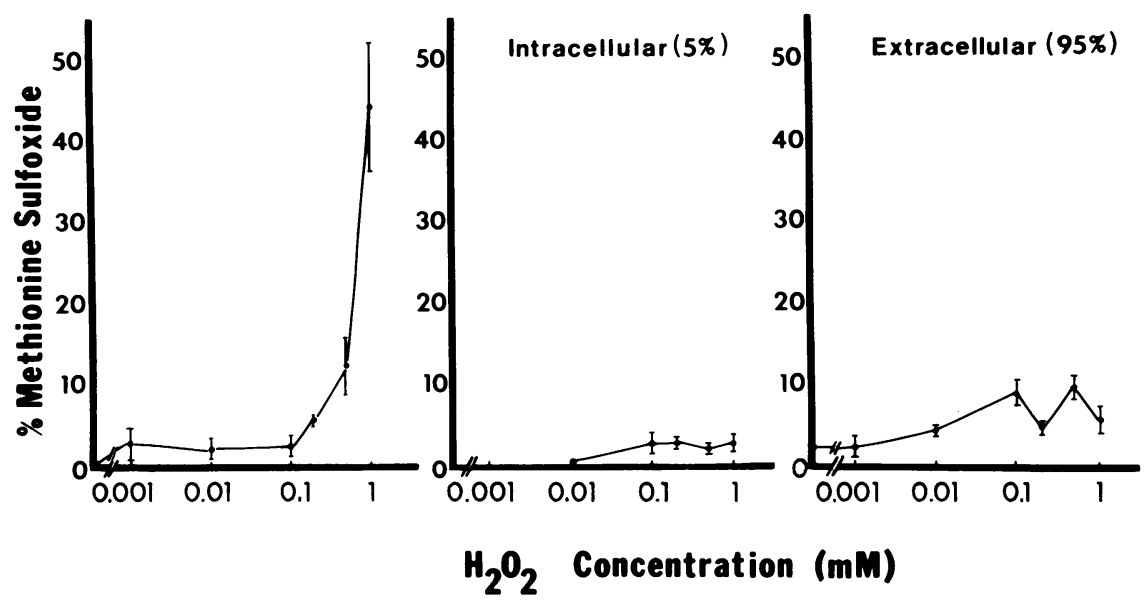

FIGURE 5 Effect of $\mathrm{H}_{2} \mathrm{O}_{2}$ on the oxidation of methionine. A reaction mixture containing 0.1 $\mu \mathrm{Ci}$ methionine $(22 \mu \mathrm{M})$ and $\mathrm{H}_{2} \mathrm{O}_{2}(0.001-1 \mathrm{mM})$ in the presence or absence of human PMN $\left(1.5 \times 10^{7}\right)$ was incubated at $37^{\circ} \mathrm{C}$ for 30 minutes. The percentage of methionine oxidized to methionine sulfoxide was then determined. In the presence of PMN, $5 \%$ of the methionine was taken up by the cells, and $95 \%$ remained extracellularly in the medium (see Fig. 2A). Each point represents the mean and SEM of four to six experiments.

studied. Tryptophan, $\mathrm{DABCO}, \mathrm{NaN}_{3}$, and $\mathrm{KCN}$ prevented the oxidation of methionine by the granular fractions (three experiments, data not shown). It should be pointed out that $\mathrm{NaN}_{3}$ again, was more potent that $\mathrm{KCN}$ in inhibiting the oxidation of methionine.

The effect of ${ }^{1} \mathrm{O}_{2}$ quenchers and MPO inhibitors on the MPO activities of granular fraction. To demonstrate that inhibition of methionine oxidation by ${ }^{1} \mathrm{O}_{2}$ quenchers was not due to their inhibition of MPO, the MPO activities of the granular fractions were measured. There was no difference in MPO activities, whether it was determined in the modified Hanks'

TABLE IV

Oxidation of Methionine by Granular Fraction of Human PMN*

\begin{tabular}{lcc}
\hline & \multicolumn{3}{c}{ Methionine sulfoxide } \\
\cline { 2 - 3 } $\mathrm{H}_{2} \mathrm{O}_{2}$ & Soluble fraction & Granular fraction \\
\hline$m M$ & $\%$ & $\%$ \\
0 & $2.5 \pm 2.5(3)$ & $2.0 \pm 1.7 \quad(4)$ \\
0.01 & $0 \pm 0 \quad(3)$ & $12.9 \pm 4.7 \quad(4)$ \\
0.02 & $3.0 \pm 3.0(3)$ & $15.6 \pm 4.9 \quad(4)$ \\
0.2 & $0 \pm 0 \quad(3)$ & $75.9 \pm 11.3(4)$
\end{tabular}

$*\left[{ }^{14} \mathrm{C}\right]$ methionine $(0.1 \mathrm{uCi}, 22 \mathrm{uM})$ was incubated with 0.15 $\mathrm{mg}$ of cell fractions (granular or soluble) in the presence or absence of $\mathrm{H}_{2} \mathrm{O}_{2}$. The percentage of methionine oxidized to methionine sulfoxide then was determined. The results are expressed as mean $\pm S E M$ of the percent methionine oxidized to methionine sulfoxide. The number in parentheses indicates the number of experiments. solution that contained $\mathrm{Cl}^{-}$or in the phosphate buffer $\left(0.1 \mathrm{M} \mathrm{pH} \mathrm{7.0)}\right.$ that did not contain $\mathrm{Cl}^{-}$. As shown in Table V, DABCO and tryptophan at a concentration of $1 \mathrm{mM}$, which markedly inhibited the oxidation of methionine (Table II) did not have any effect on the MPO activities of the granular fractions. $\mathrm{NaN}_{3}(1 \mathrm{mM})$, while markedly inhibiting the oxidation of methionine (90\% inhibition), inhibited the MPO activities by only $18 \%$. In contrast, $\mathrm{KCN}$ at the similar concentration markedly inhibited the oxidation of methionine and the MPO activities.

The effect of $\mathrm{Cl}^{-}$on the oxidation of methionine by the granular fraction. Our results suggest that the oxidation of methionine by phagocytosing PMN or the granular fraction is dependent on MPO and $\mathrm{H}_{2} \mathrm{O}_{2}$. To determine whether the MPO-mediated antimicrobial system (MPO- $\left.\mathrm{H}_{2} \mathrm{O}_{2}-\mathrm{Cl}^{-}\right)$(1) is responsible for this oxidation, the effect of $\mathrm{Cl}^{-}$was then studied. When $\mathrm{Cl}^{-}$was eliminated from the incubation medium by replacing modified Hanks' solution with phosphate buffer $(0.1 \mathrm{M}, \mathrm{pH} 7.0)$, oxidation of methionine by the granular fraction was markedly reduced, but not completely abolished $(32.3 \pm 8.4 \%$ vs. control 86.9 $\pm 6.5 \% n=5, P<0.001)$. This might be due to a slight contamination of $\mathrm{Cl}^{-}$in the granular fractions. This reduced oxidation of methionine by the granular fraction in the absence of $\mathrm{Cl}^{-}$was not due to the inhibition of MPO, since MPO functioned normally in the absence of $\mathrm{Cl}^{-}$(see above).

Effect of $\mathrm{D}_{2} \mathrm{O}$ on the oxidation of methionine by human PMN and the granular fraction. The lifetime of ${ }^{1} \mathrm{O}_{2}$ is much longer in $\mathrm{D}_{2} \mathrm{O}$ than in $\mathrm{H}_{2} \mathrm{O}(26)$ and it has 
TABLE V

Effect of Singlet Oxygen Quenchers and Myeloperoxidase Inhibitors on the Peroxidase Activities of the Granular Fraction of Human PMN*

\begin{tabular}{|c|c|c|c|}
\hline & & Peroxidase activity & $\begin{array}{c}P \text { value } \\
\text { (vs. control) }\end{array}$ \\
\hline & \multicolumn{3}{|c|}{ 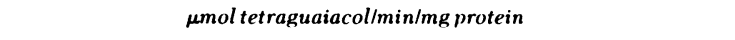 } \\
\hline Control & & $2.88 \pm 0.60(3)$ & \\
\hline +DABCO & $1 \mathrm{mM}$ & $2.96 \pm 0.46(3)$ & $>0.8$ \\
\hline +Tryptophan & $1 \mathrm{mM}$ & $2.82 \pm 0.12(3)$ & $>0.8$ \\
\hline$+\mathrm{NaN}_{3}$ & $1 \mathrm{mM}$ & $2.38 \pm 0.53(3)$ & $<0.025$ \\
\hline$+\mathrm{KCN}$ & $1 \mathrm{mM}$ & $0.01 \pm 0.01(3)$ & $<0.001$ \\
\hline
\end{tabular}

* Guaiacol was used as the hydrogen donor. The results are expressed as the mean $\pm 1 \mathrm{SEM}$ (micromoles tetraguaiacol produced/minute/milligram protein).

been suggested that enhancement of ${ }^{1} \mathrm{O}_{2}$-mediated reaction in $\mathrm{D}_{2} \mathrm{O}$ is one way of demonstrating ${ }^{1} \mathrm{O}_{2}$ intermediacy $(12,26)$. The effect of $\mathrm{D}_{2} \mathrm{O}$ on the oxidation of methionine by human PMN and the granular fraction was then studied. For this purpose, the concentration of methionine was increased to $102 \mu \mathrm{M}$ (instead of $22 \mu \mathrm{M}$ used in the above experiments). As shown in Table VI, $\mathrm{D}_{2} \mathrm{O}$ had no effect on the methionine oxidation by resting $\mathrm{PMN}$, while it markedly stimulated the methionine oxidation by granular fractions. Since at higher concentrations, $\mathrm{H}_{2} \mathrm{O}_{2}$ can oxidize methionine, the effect of $\mathrm{D}_{2} \mathrm{O}$ was also studied. $\mathrm{D}_{2} \mathrm{O}$ had no effect on the oxidation of methionine by $\mathrm{H}_{2} \mathrm{O}_{2}$ $\left(34.6 \pm 8.2 \%\left[\mathrm{H}_{2} \mathrm{O}\right]\right.$ vs. $34.0 \pm 2.3 \%\left[60 \% \mathrm{D}_{2} \mathrm{O}\right], \mathrm{H}_{2} \mathrm{O}_{2}$ $1 \mathrm{mM}$, methionine $22 \mu \mathrm{M}$, mean $\pm \mathrm{SEM}$ of three experi-

TABLE VI

Effect of $\mathrm{D}_{2} \mathrm{O}$ on the Oxidation of Methionine by Human PMN and Granular Fractions*

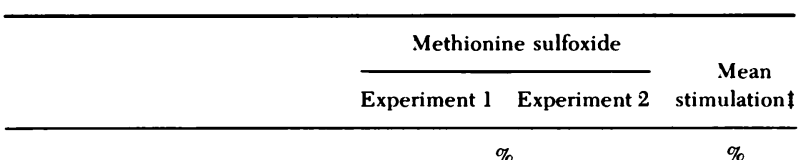

\begin{tabular}{|c|c|c|c|c|}
\hline \multicolumn{5}{|l|}{ Human PMN } \\
\hline \multirow[t]{2}{*}{ Resting } & $\mathrm{H}_{2} \mathrm{O}$ & 2.5 & 0 & \\
\hline & $\mathrm{D}_{2} \mathrm{O}$ & 1.8 & 0 & - \\
\hline \multirow[t]{2}{*}{ Phagocytosing } & $\mathrm{H}_{2} \mathrm{O}$ & 22.6 & 16 & \\
\hline & $\mathrm{D}_{2} \mathrm{O}$ & 53.1 & 59.7 & 192 \\
\hline \multicolumn{5}{|l|}{ Granular fraction } \\
\hline \multirow[t]{2}{*}{ Alone } & $\mathrm{H}_{2} \mathrm{O}$ & 1.4 & 0 & \\
\hline & $\mathrm{D}_{2} \mathrm{O}$ & 0 & 0 & - \\
\hline \multirow[t]{2}{*}{$+\mathrm{H}_{2} \mathrm{O}_{2}(0.2 \mathrm{mM})$} & $\mathrm{H}_{2} \mathrm{O}$ & 18.8 & 15.9 & \\
\hline & $\mathrm{D}_{2} \mathrm{O}$ & 46.3 & 57.9 & 200 \\
\hline
\end{tabular}

* The experimental conditions were the same as in Table I and Table $\mathrm{V}$ except that the concentration of methionine was 102 $\mu \mathrm{M}$. When $\mathrm{D}_{2} \mathrm{O}$ was used, its final concentration was $60 \%$. f Percent stimulation of methionine oxidation in $\mathrm{D}_{2} \mathrm{O}$ over $\mathrm{H}_{2} \mathrm{O}$. ments). In addition, $\mathrm{D}_{2} \mathrm{O}(60 \%)$ had no effect on either the $\mathrm{O}_{2}^{-}$production by phagocytosing PMN or the MPO activity of the granular fractions (three experiments, data not shown).

Oxidation of methionine by $\mathrm{NaOCl}$ and methylene blue. The formation of hypochlorous acid by MPO, $\mathrm{H}_{2} \mathrm{O}_{2}$, and $\mathrm{Cl}^{-}(13)$ and the generation of ${ }^{1} \mathrm{O}_{2}$ by hypochlorite and $\mathrm{H}_{2} \mathrm{O}_{2}(6,12)$ have led Rosen and Klebanoff (5) to suggest that this may be the mechanism that ${ }^{1} \mathrm{O}_{2}$ is produced by $\mathrm{PMN}$ during phagocytosis. Since hypochlorite is a potent oxidizing agent, it is possible that the oxidation of methionine by $\mathrm{MPO}-\mathrm{H}_{2} \mathrm{O}_{2}-\mathrm{Cl}^{-}$ system is mediated by hypochlorite, rather than ${ }^{1} \mathrm{O}_{2}$. In fact, it has been shown that the presumed ${ }^{1} \mathrm{O}_{2}$ reaction described by Rosen and Klebanoff (5) is due to chlorine instead of ${ }^{1} \mathrm{O}_{2}$ (13). As shown in Fig. 6, hypochlorite oxidized methionine to methionine sulfoxide (hypochlorite at concentrations higher than $0.02 \mathrm{mM}$ oxidized methionine to a new product with a $R_{\mathrm{f}}$ value of 0.82 in the solvent system I). Addition of $\mathrm{H}_{2} \mathrm{O}_{2}$ did not enhance the oxidation of methionine. Furthermore, $\mathrm{D}_{2} \mathrm{O}$ did not have any effect on the oxidation of methionine by hypochlorite either in the presence or absence of $\mathrm{H}_{2} \mathrm{O}_{2}$. As a control experiment for comparison, photodynamic oxidation of methionine by methylene blue, a known ${ }^{1} \mathrm{O}_{2}$-mediated reaction $(11,12)$, was enhanced by $\mathrm{D}_{2} \mathrm{O}$ (two experiments, data not shown).

\section{DISCUSSION}

In this study, we demonstrated that phagocytosing human PMN, but not resting PMN, oxidized both intracellular and extracellular methionine to methionine sulfoxide. $\mathrm{N}$-ethylmaleimide, which inhibits phagocytosis and cellular metabolism, inhibited the oxidation of methionine. Neutrophils from patients with CGD failed to oxidize methionine even in the presence of phagocytosis. Thus, the oxidation of methionine by phagocytosing PMN is dependent upon the oxidative metabolism normally associated with phagocytosis. 


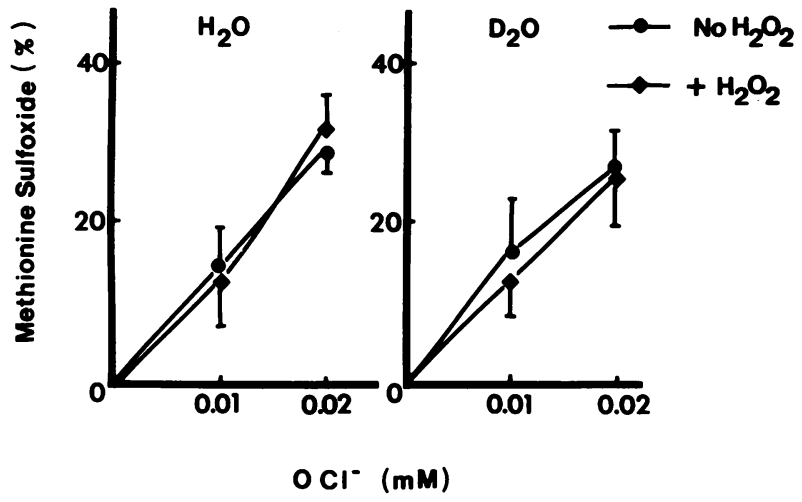

FIgURE 6 Oxidation of methionine by sodium hypochlorite. Methionine $(0.1 \mu \mathrm{Ci}, 22 \mu \mathrm{M})$ and $\mathrm{NaOCl}$ were incubated in the presence and absence of $\mathrm{H}_{2} \mathrm{O}_{2}(0.1 \mathrm{mM})$ in a final vol of $1 \mathrm{ml}$ in phosphate buffer $(\mathrm{pH} 8.5)$ for $10 \mathrm{~min}$ at $37^{\circ} \mathrm{C}$. The percent oxidation of methionine was then determined. When $\mathrm{D}_{2} \mathrm{O}$ was used, its final concentration was $60 \%$. Mean \pm SEM of four experiments. Similar results were obtained when the experiment was performed in modified Hanks' solution ( $\mathrm{pH} 7.4$ ).

From the data presented, it is clear that the oxidation of methionine by phagocytosing PMN was not due to $\mathrm{O}_{2}^{-}$or $\mathrm{OH} \cdot$. On the other hand, the oxidation of methionine by phagocytosing P.MN was at least in part dependent on $\mathrm{H}_{2} \mathrm{O}_{2}$. However, there are several pieces of evidence suggesting that the oxidation of methionine is not directly mediated by $\mathrm{H}_{2} \mathrm{O}_{2}$. First, $\mathrm{KCN}$, a potent heme enzyme inhibitor, inhibited the oxidation of methionine by phagocytosing PMN. In the presence of $\mathrm{KCN}$, catalase and MPO are inhibited. As a result, more $\mathrm{H}_{2} \mathrm{O}_{2}$ is released by phagocytosing PMN (27). If the oxidation of methionine by phagocytosing PMN was due to the direct oxidation of methionine by $\mathrm{H}_{2} \mathrm{O}_{2}$, then KCN-treated PMN would have oxidized more methionine. Second, when $\mathrm{H}_{2} \mathrm{O}_{2}$, at concentrations sufficiently high to oxidize methionine, was added to PMN it did not significantly oxidize methionine. In contrast, when $\mathrm{H}_{2} \mathrm{O}_{2}$ (at concentrations too low to oxidize methionine) was added to the granular fractions, it oxidized methionine to methionine sulfoxide. Third, the oxidation of methionine by $\mathrm{H}_{2} \mathrm{O}_{2}$ was not enhanced by $\mathrm{D}_{2} \mathrm{O}$, whereas the oxidation of methionine by phagocytosing PMN was markedly stimulated by $\mathrm{D}_{2} \mathrm{O}$. Thus, it is more likely that the combination of a KCN-sensitive enzyme (or enzymes) and $\mathrm{H}_{2} \mathrm{O}_{2}$ is responsible for the oxidation of methionine.

Three pieces of evidence support the possibility that the oxidation of methionine by phagocytosing PMN was due to the production of ${ }^{1} \mathrm{O}_{2}$. First, ${ }^{1} \mathrm{O}_{2}$ can oxidize methionine to methionine sulfoxide. The bulk of evidence comes from studies of photosensitized oxidation of methionine $(11,12)$. Second, the oxidation of methionine by phagocytosing PMN was inhibited by ${ }^{1} \mathrm{O}_{2}$ quenchers. In this study, we only used water soluble quenchers, DABCO (22), tryptophan (12), and $\mathrm{NaN}_{3}(23)$. There are many other ${ }^{1} \mathrm{O}_{2}$ quenchers such as $\beta$-carotene, bilirubin, and dimethylfuran (12). However, these lipid soluble ${ }^{1} \mathrm{O}_{2}$ quenchers have very limited water solubility. The vehicles used to dissolve sufficient quantities of these quenchers are found to be detrimental to the cells. Third, the oxidation of methionine by phagocytosing PMN was markedly enhanced by $\mathrm{D}_{2} \mathrm{O}$, a known phenomenon of ${ }^{1} \mathrm{O}_{2}$ mediated reaction $(12,26)$.

There are several mechanisms that ${ }^{1} \mathrm{O}_{2}$ may be produced by phagocytosing PMN. These include:

The spontaneous dismutation of $\mathrm{O}_{2}^{-}(28)$

$$
\mathrm{O}_{2}^{-}+\mathrm{O}_{2}^{-}+2 \mathrm{H}^{+} \rightarrow{ }^{1} \mathrm{O}_{2}+\mathrm{H}_{2} \mathrm{O}_{2}
$$

The interaction of $\mathrm{O}_{2}^{-}$and $\mathrm{OH} \cdot(29)$,

$$
\mathrm{O}_{2}^{-}+\mathrm{OH} \cdot \rightarrow{ }^{1} \mathrm{O}_{2}+\mathrm{OH}^{-}
$$

The interaction of $\mathrm{O}_{2}^{-}$and $\mathrm{H}_{2} \mathrm{O}_{2}$ in the presence of a metal ion (Haber-Weiss reaction) (30).

$$
\mathrm{O}_{2}^{-}+\mathrm{H}_{2} \mathrm{O}_{2} \rightarrow{ }^{1} \mathrm{O}_{2}+\mathrm{OH}^{-}+\mathrm{OH} \text {. }
$$

The reaction of $\mathrm{H}_{2} \mathrm{O}_{2}$ with $\mathrm{OCl}^{-}$produced by the action of the $\operatorname{MPO}(5,6,13)$.

$$
\begin{gathered}
\mathrm{H}_{2} \mathrm{O}_{2}+\mathrm{Cl}^{-} \stackrel{\text { MOP }}{\longrightarrow} \mathrm{H}_{2} \mathrm{O}+\mathrm{OCl}^{-} \\
\mathrm{H}_{2} \mathrm{O}_{2}+\mathrm{OCl}^{-} \longrightarrow \mathrm{H}_{2} \mathrm{O}+\mathrm{Cl}^{-}+{ }^{1} \mathrm{O}_{2}
\end{gathered}
$$

If the oxidation of methionine by phagocytosing PMN was due to ${ }^{1} \mathrm{O}_{2}$, then mechanism $1-3$ did not produce sufficient ${ }^{1} \mathrm{O}_{2}$ to oxidize methionine, since SOD did not have any effect on the methionine oxidation. On the other hand, the evidence presented in this paper, suggest that the oxidation of methionine is largely dependent upon the MPO-mediated antimicrobial system ( $\left.\mathrm{MPO}-\mathrm{H}_{2} \mathrm{O}_{2}-\mathrm{Cl}^{-}\right)$. Although we have not actually used MPO, yet the cellular location (granular fraction) and the response to inhibitor suggest that MPO is most likely the enzyme involved. Thus, one would suggest that mechanism 4 was most likely responsible for the production of ${ }^{1} \mathrm{O}_{2}$ and the oxidation of methionine. If this were the case, then the combination of $\mathrm{OCl}^{-}$and $\mathrm{H}_{2} \mathrm{O}_{2}$ should oxidize methionine to methionine sulfoxide. Unfortunately, $\mathrm{OCl}^{-}$alone oxidized methionine, the addition of $\mathrm{H}_{2} \mathrm{O}_{2}$ did not enhance the oxidation of methionine. Furthermore, $\mathrm{D}_{2} \mathrm{O}$ did not enhance the oxidation of methionine by either $\mathrm{OCl}^{-}$or the combination of $\mathrm{OCl}^{-}$and $\mathrm{H}_{2} \mathrm{O}_{2}$. Since $\mathrm{D}_{2} \mathrm{O}$ did not enhance the oxidation of methionine by $\mathrm{OCl}^{-}$, it suggests that the oxidation of methionine by phagocytosing PMN or by the combination of granular fraction, $\mathrm{H}_{2} \mathrm{O}_{2}$ and $\mathrm{Cl}^{-}$was not due to $\mathrm{OCl}^{-}$. Failure to show $\mathrm{D}_{2} \mathrm{O}$ enhancement of methionine oxidation by $\mathrm{OCl}^{-}$and $\mathrm{H}_{2} \mathrm{O}_{2}$ suggests that ${ }^{1} \mathrm{O}_{2}$ was not produced by $\mathrm{OCl}^{-}$and $\mathrm{H}_{2} \mathrm{O}_{2}$ in sufficient quantity to oxidize 
methionine. We might not have used the optimal condition for the production of ${ }^{1} \mathrm{O}_{2}$ by $\mathrm{OCl}^{-}$and $\mathrm{H}_{2} \mathrm{O}_{2}$, though we have performed the experiment at $\mathrm{pH} 8.5$, which favors the production of ${ }^{1} \mathrm{O}_{2}$ from $\mathrm{OCl}^{-}$and $\mathrm{H}_{2} \mathrm{O}_{2}$ $(26,31)$.

Although our results are compatible with the production of ${ }^{1} \mathrm{O}_{2}$ by phagocytosing PMN, because of the nonspecific nature of the chemical reaction and quenchers used, one really cannot be sure that the oxidation of methionine by phagocytosing PMN or the MPO-mediated antimicrobial system is actually due to ${ }^{1} \mathrm{O}_{2}$. For example, $\mathrm{NaN}_{3}$ and tryptophan are shown to be $\mathrm{OH} \cdot$ scavengers (32) as well as ${ }^{1} \mathrm{O}_{2}$ quenchers $(11,12,23)$. Recently Held and Hurst (31) have demonstrated that hypochlorous acid preferentially oxidizes DABCO in the presence of $\mathrm{H}_{2} \mathrm{O}_{2}$ without intermediary formation of ${ }^{1} \mathrm{O}_{2}$. Furthermore, the effect of $\mathrm{D}_{2} \mathrm{O}$ is not specific for ${ }^{1} \mathrm{O}_{2}$-mediated reaction (33). No matter what is responsible for the oxidation of methionine by phagocytosing PMN, if phagocytosing PMN also oxidizes methionine present at the active site of enzymes, this may be one of the mechanisms by which PMN damage microorganisms. Recently, Matheson et al. (34) have demonstrated that MPO, in the presence of $\mathrm{H}_{2} \mathrm{O}_{2}$ and halide ion, catalytically inactivates alpha-1-proteinase inhibitor. Amino acid analysis of the inactivated alpha-1-proteinase inhibitor reveals that methionine, which is present at the active site, is oxidized to methionine sulfoxide.

\section{ACKNOWLEDGMENTS}

The authors are grateful to Miss Berlina Newman for her technical assistance and Ms. Denise Springer for her secretarial work.

This work was supported by the Public Health Service research grants AI-13004, AI-15431, and GM-10548.

\section{REFERENCES}

1. Klebanoff, S. J. 1975. Antimicrobial mechanisms in neutrophilic polymorphonuclear leukocytes. Semin. Hematol. 12: 117-142.

2. Babior, B. M., R. S. Kipnes, and J. T. Curnutte. 1973. Biological defense mechanism: the production by leukocytes of superoxide, a potential bactericidal agent. $J$. Clin. Invest. 52: 741-744.

3. Babior, B. M., J. T. Curnutte, and B. J. McMurnich. 1976. The particulate superoxide-forming system from human neutrophils, properties of the system and further evidence supporting its participation in the respiratory burst. J. Clin. Invest. 58: 989-996.

4. Tauber, A. I., and B. M. Babior. 1977. Evidence for hydroxyl radical production by human neutrophils. $J$. Clin. Invest. 60: 374-379.

5. Rosen, H., and S. J. Klebanoff. 1977. Formation of singlet oxygen by the myeloperoxidase mediated antimicrobial system. J. Biol. Chem. 252: 4803-4810.

6. Kearns, D. R. 1971. Physical and chemical properties of singlet molecular oxygen. Chem. Rev. 71: 385-427.

7. Allen, R. C., R. L. Stjerholm, and R. H. Steele. 1972.
Evidence for the generation of an electronic excitation state(s) in human polymorphonuclear leukocytes and its participation in bactericidal activity. Biochem. Biophys. Res. Commun. 47: 679-684.

8. Cheson, B. D., R. L. Christensen, R. Sperling, B. E. Kohler, and B. M. Babior. 1976. The origin of the chemiluminescence of phagocytosing granulocytes. J. Clin. Invest. 58: 789-796.

9. Krinsky, N. I. 1974. Singlet excited oxygen as a mediator of the antibacterial action of leukocytes. Science (Wash. D. C.). 186: 363-365.

10. Harrison, J. D., B. D. Watson, and J. Schultz. 1978. Myeloperoxidase and singlet oxygen: a re-appraisal. FEBS (Fed. Eur. Biochem. Soc.) Lett. 92: 327-332.

11. Jori, G., G. Gabiazzo, A. Marzotto, and E. Scoffone. 1968. Dye-sensitized selective photo-oxidation of methionine. Biochim. Biophys. Acta. 154: 1-9.

12. Foote, C. S. 1976. Photosensitized oxidation and singlet oxygen: consequences in biological systems. In Free Radicals in Biology. William A. Pryor, editor. Academic Press, Inc., New York. II: 85-133.

13. Harrison, J. E., and J. Schultz. 1976. Studies on the chlorinating activity of myeloperoxidase. J. Biol. Chem. 251: 1371-1374.

14. Tsan, M. F., and P. A. McIntyre. 1976. The requirement for membrane sialic acid in the stimulation of superoxide production during phagocytosis by human polymorphonuclear leukocytes.J. Exp. Med. 143: 1308-1316.

15. Tsan, M. F., and P. A. McIntyre. 1975. Stimulation by propylthiouracil of the hexose monophosphate shunt in human polymorphonuclear leukocytes during phagocytosis. Br. J. Haematol. 31: 193-208.

16. Fink, K., R. E. Cline, and R. M. Fink. 1965. Paper chromatography of several classes of compounds: correlated $\mathbf{R}_{\mathrm{f}}$ values in a variety of solvent systems. Anal. Chem. 35: 389-398.

17. Tsan, M. F., and R. D. Berlin. 1971. Membrane transport in the rabbit alveolar macrophage, the specificity and characteristics of amino acid transport systems. Biochem. Biophys. Acta. 240: 155-169.

18. Michell, R. H., M. J. Karnovsky, and M. L. Karnovsky. 1970. The distributions of some granule-associated enzymes in guinea pig polymorphonuclear leukocytes. Biochem. J. 116: 207-216.

19. Tsan, M. F., K. H. Douglass, and P. A. McIntyre. 1977. Hydrogen peroxide production and killing of Staphylococcus aureus by human polymorphonuclear leukocytes. Blood. 49: 437-444.

20. Croxton, F. E. 1953. Elementary Statistics with Applications in Medicine and the Biological Sciences. Dover Publications, Inc., New York. 235-244.

21. Tsan, M. F., B. Newman, and P. A. McIntyre. 1976. Surface sulphydryl groups and phagocytosis-associated oxidative metabolic changes in human polymorphonuclear leukocytes. Br. J. Haematol. 33: 189-204.

22. Quannes, C., and T. Wilson. 1968. Quenching of singlet oxygen by tertiary aliphatic amines. Effect of DABCO. J. Am. Chem. Soc. 90: 6526-6528.

23. Gollrice, K., D. Haisch, and G. Schade. 1972. Is the concerted "Ene" mechanism of the ${ }^{1} \Delta \mathrm{g}$ excited oxygen molecule reactions with olefins really eliminated? Photooxygenation and electrolysis in the presence of azide ions. J. Am. Chem. Soc. 95: 1747-1748.

24. Agner, K. 1941. Verdoperoxidase. A ferment isolated from leukocytes. Acta Physiol. Scand. 2 (Suppl. 8): 5-62.

25. Toennies, G., and J. J. Golb. 1939. Methionine studies II. DL-methionine sulfoxide.J. Biol. Chem. 128: 399-405.

26. Kajiwara, T., and D. R. Dearn. 1973. Direct spectro- 
scopic evidence for a deuterium solvent effect on the lifetime of singlet oxygen in water. J. Am. Chem. Soc. 95: 5886-5890.

27. Noseworthy, J., and M. L. Karnovsky. 1972. Role of peroxide in the stimulation of hexose monophosphate shunt during phagocytosis by polymorphonuclear leukocytes. Enzyme (Basel). 13: 110-131.

28. Khan, A. U. 1970. Singlet molecular oxygen from superoxide anion and sensitized fluorescence of organic molecules. Science (Wash. D. C.). 168: 476-477.

29. Anderson, R. M. 1970. Substrate-induced chemiluminescence of xanthine oxidase and aldehyde oxidase. Arch. Biochem. Biophys. 136: 352-360.

30. Haber, F., and J. Weiss. 1934. The catalytic decomposition of hydrogen peroxide by iron salt. Proc. R. Soc. Edinb. Sect. A (Math. Phys. Sci.). 147: 332-351.
31. Held, A. M., and J. K. Hurst. 1978. Ambiguity associated with the use of singlet oxygen trapping agents in myeloperoxidase-catalyzed oxidation. Biochem. Biophys. Res. Commun. 81: 871-885.

32. Kraljic, I., and C. N. Trumbore. 1965. $p$-Nitrosodimethylaniline as an $\mathrm{OH}$ radical scavenger in radiation chemistry. J. Am. Chem. Soc. 87: 2547-2550.

33. Swain, C. G., and A. D. Ketley. 1955. The chlorinium ion as an intermediate in chlorination of aromatic compounds by hypochlorous acid. J. Am. Chem. Soc. 77: 3410 .

34. Matheson, N. R., P. S. Wong, and J. Travis. 1979. Enzymatic inactivation of human alpha-1-proteinase inhibitor by neutrophil myeloperoxidase. Biochem. Biophys. Res. Commun. 88: 402-409. 